\title{
A Touch of Heterodoxy: Friedrich Klopstock's Der Messias and the Case of Thomas the Apostle
}

\author{
Matthew Stoltz
}

\section{Heilige Poesie as a Poetics of Skepticism}

If there was one biblical figure that Friedrich Klopstock took special care in developing for his epic retelling of the New Testament it was "Doubting Thomas." The apostle Thomas, famously known for refusing to believe in Christ's resurrection without being presented empirical evidence, casts a long and remarkable shadow over much of Klopstock's literary career. A pair of poems, "Das Anschaun Gottes« and "Ode über die Allgegenwart Gottes, " composed in the I750s and later revised in the I790s indicate that Klopstock sustained his interest in Thomas's skepticism. ${ }^{\mathrm{I}}$ In fact, not only do both titles allude to the relevant theme of evidence, each concludes by restating Thomas's words of conversion as cited in the Lutheran Bible: "Mein Herr! und mein Gott! $\aleph^{2}$ Of interest to the present study are two epigraphs that accompany these poems. The first, quotes a passage from the Book of Job whereby Job, after experiencing horrific physical abuses, manages to find a spark of hope within himself asserting confidently that: "my redeemer lives; I will see him in my flesh and with my own eyes" (HKA I/I, I60). ${ }^{3}$ Despite ample evidence to suggest that Job's God might not actually care about his fate, he nevertheless believes by looking inward for "intuitions". Job's inner determination makes his outward suffering bearable. Thomas, by contrast, fails to learn this lesson from Job, which internalizes suffering and makes Thomas's "verwundete Seele» agonize all the more (HKA I/I, I6I). The second epigraph argues that concepts like divine omnipresence "[können] nichts anders als poetisch ausgedrückt werden, « meaning that poetic representation plays a critical role in generating the kinds of (religious) intuitions that led to Job's inwardly determined faith (HKA I/I, I 44). This presupposition would indeed make poetry seem "heilig" in its capacity to facilitate religious conviction by means of poetic representation - a heterodox idea if there ever was one. But before analyzing Klopstock's theory of "heilige Poesie« in relation to Doubting Thomas, some context about the wider significance of this apostle is needed.

Thomas has always been a controversial figure in the biblical tradition. He was, for instance, nearly written out of the canon by the synoptic tradition (the Gospels of Mark, Luke, and Matthew). These texts, which represent the earliest and most consistent reports of Christ's life and teach- 
ings, only list Thomas's name as a minor figure, and instead of focusing on his doubts about Christ's resurrection they develop scenarios that generate further skepticism. For example, the Gospel of Mark inadvertently led to a theory according to which Christ's body was stolen rather than resurrected. ${ }^{4}$ Luke's Gospel left open the possibility that the grief-stricken apostles saw only an apparition of Christ. ${ }^{5}$ And finally, the Gospel of Matthew communalized the problem of doubt by claiming that there were "still doubters among " the apostles even after they saw Christ resurrected at Galilee. ${ }^{6}$ But only the Gospel of John - a text composed much later than the other gospels - decided to flesh out the figure of Thomas and give him a lead role. Hoping to dispel any residual skepticism left over from his predecessors, ${ }^{7}$ John summoned all his talents as a storyteller to put Thomas's disbelief into the service of faith so that posterity would never forget the proverb »it is better to believe than to see. ${ }^{8}$ However, tradition does not remember $\mathrm{Be}$ lieving Thomas, «9 but rather »Doubting Thomas, « the transgressive apostle who refused to ground his faith on hearsay alone; the one who demanded nothing less than to see and touch the wounds of Christ. ${ }^{\text {Io }}$ Consequently, this demand shrouded Thomas's reception throughout cultural history in ambiguity, ensuring that John would not have the final word on him.

In the eighteenth century, the problem of Doubting Thomas is restaged in a number of powerful ways. ${ }^{\text {II }}$ More so than any other apostle, Thomas lives up to Kant's call to think for oneself because he exhibits the courage to use his own understanding and refuses to blindly assent to the authority of others. ${ }^{\mathrm{I} 2}$ Nevertheless Thomas's situation remains unique in that he does not merely think eternal salvation awaits humanity, he knows it. ${ }^{13}$ His religious knowledge is constitutive rather than regulative, ${ }^{\mathrm{I} 4}$ which means that he does not need to think and act as if God exists and will reward the virtuous because he has seen this promise fulfilled in Christ with his own eyes. Of course, no such faith was available to eighteenth-century theologians, who defiantly strove to forge systems of faith that used the same standards and procedures of natural science. ${ }^{\mathrm{I} 5}$ This effort to establish a more "certain « faith indexes the figure of Doubting Thomas. The relevance of Doubting Thomas was especially prominent during the Fragmentenstreit (I773-80) when Lessing charged his peers with turning scripture into a tower of Babel, ${ }^{16}$ showing them how their desire to deduce necessary truths of reason from the gospels transposed the problem of Doubting Thomas into the broader realm of historical judgment. ${ }^{17}$

Yet before these inquiries made Thomas a figure of grounded knowledge, Klopstock attempted to poetically succeed where John had failed. Der Messias conjugates the Thomas episode into the idiom of epic poetry in the hope of making the moral lesson of belief more audible to an increasingly skeptical modernity. Ironically, Klopstock's attempt to touch or move his 
audience by reenergizing this biblical episode draws him closer into the party of skepticism than he perhaps realized. ${ }^{18}$ This, in part, is due to the sprawling scope of Klopstock's version of Doubting Thomas, which threatens to unravel the pious intentions of his poetics. ${ }^{\text {I9 }}$ Whereas John's exposition of Thomas involves only a few lines of verse, Klopstock expands the tale of incredulity to a staggering I,400 lines - nearly all of Gesang XIV. Such a prolix adaptation of the Thomas scene demonstrates how Klopstock had very little trust in the revelatory power of the original story; that he found its truth too weak, too soft-spoken, and too full of gaps to be of any service to modern readers. As a result, he tried to supplement the original story by dramatizing the affective states associated with skepticism, but in so doing created new gaps and new discrepancies that intensify the ambiguity of the original story. Klopstock's amplification of Thomas produces what Kevin Hilliard has described as a "Krise der Legitimation, " in which literary and aesthetic attempts to dispel skepticism inherently risk producing the opposite effect. ${ }^{20}$ In the case of Der Messias, Klopstock's representation of Doubting Thomas destabilizes the traditionally negative status of skepticism within a Christian imaginary.

In addition to the scale of Klopstock's amplification, the underlying poetics of Der Messias reproduces the same tragic fallacy as Thomas by doubting the efficacy of scripture alone [sola scriptura] to reveal religious truths. To support this claim I will interrogate Klopstock's approach to scripture as outlined in his 1755 essay "Von der heiligen Poesie, " a document that served as the preface to the 1756 edition of Der Messias. After identifying how the poetics of Der Messias is itself circumscribed by skepticism, I then develop a close reading of Klopstock's Thomas to get a sense of how the poem confronts modern skepticism.

Most conventional readings of Doubting Thomas tend to limit his significance to that of a negative example. ${ }^{21}$ In defending this view, commentators often cite Christ's own assessment of Thomas's faith: »Because you have seen me, you have believed; blessed are those who have not seen and yet believed. ${ }^{22}$ St. Augustine, for example, understood Christ's words not only as an imperative, but also used them to draw rigid boundaries between faith and reason, arguing that faith is required to grasp the miracles and prophecies of revealed knowledge. ${ }^{23}$ However, by the eighteenth century new discourses on freedom had been absorbed into popular morality, greatly diminishing the legitimacy of the obedience model of faith (Glaubenspflicht). As a result, older interpretations needed updating to accommodate the new environment of "enlightened « faith. For instance, Johann Wilhelm Friedrich Jerusalem, a pioneering figure of enlightenment theology and avid supporter of Klopstock, ${ }^{24}$ used a historical-critical approach to scripture to supersede Augustine's dismal account of original sin 
that views human nature as unable to actualize virtuous life without divine grace. $^{25}$ Against this interpretation, Jerusalem protests: "Wo steht es, daß die Menschen ihres angeborenen Verderbens wegen verdammt werden sollen? « ${ }^{26}$ Jerusalem found no evidence in scripture to support Augustine's interpretation, allowing him to accord free will a more dignified status and to argue that just because humans are born sinful that does not mean they lack an innate capacity for virtue. That innate capacity, according to Jerusalem's reworking of original sin, is revealed across human history, which records countless examples of individuals freely electing to participate in virtuous life. Jerusalem's approach to scripture helped clear a path for Enlightenment theologians seeking to revise ambiguous and unpopular doctrines.

Ambiguous scenes like the one involving Doubting Thomas were therefore primed for this kind of revision. One inevitable result of Klopstock's retelling of the gospel narratives involved controversial debates about whether or not Der Messias should be viewed as a monument to orthodoxy or heterodoxy. These disagreements are well-documented in Gerhard Kaiser's study Religion und Dichtung, which chronicles responses ranging from a satire that involves the devil reading Klopstock's tediously orthodox poem as a bedtime story, to the more heterodox implications of a secular work of art rising to the status of a cult religion. ${ }^{27}$ It is precisely these kinds of disagreements that make Klopstock's religious poetry a subject of renewed interest. My interest is not to show how the contents Der Messias adheres to or deviates from orthodoxy or heterodox — terms not easy to define-but more to show how the elocutionary project of "heilige Poesie« cannot escape charges of heterodoxy.

In Klopstock's essay "Von der heiligen Poesie« he states his intention to amplify biblical episodes that lack sufficient details and to make the moral truths of the bible more forceful:

Die moralische Wahrheit der Bibel, besonders da, wo sie eine Stufe höher, als die philosophische, steigt, muss in ihrer vollen Stärke gesagt werden; aber nicht mürrisch und trübsinnig. Die Offenbarung ist beides nicht. Sie ist Ernst. Einige heilige Begebenheiten lassen ebenso wenig eine Ausbildung zu, als sie andre zu fordern scheinen. (HKA IX/I, 4I)

This passage provides insight into Klopstock's broader religious thought, which links the moral truth of the bible to poetic representation. By contrast, Klopstock characterizes philosophy as an inadequate vehicle for communicating the moral truths of the bible because it fails to express those truths with the full emotional intensity they deserve. ${ }^{28}$ Klopstock then asserts that certain biblical events require more poetic amplification than others, as if the events themselves called out for elaboration, a subterfuge 
minimizing Klopstock's own role in a highly subjective process. Paradoxically, Klopstock cautions against too much poetic amplification: »Ich nenne schon Irrtum, wenn man zuweilen da hundert Schritte sehn will, wo man nur einige sehn sollte, und wenn man sehn will, wo man nur glauben sollte« (HKA IX/I, 4I). Considering Klopstock's expansive amplification of the Thomas episode, it becomes painfully obvious that he violates his own rule.

To want to see more in cases where one should simply believe in the available reports brings the poetics of Der Messias dangerously close to the figure of Doubting Thomas. Like Thomas, Klopstock elaborates scripture on the assumption that a more forceful, immanent truth can be revealed, but in order to decipher that truth he must doubt scripture. Klopstock argues, „Gewisse Wahrheiten, deren völlige Erkenntnis uns in diesem Leben noch nicht notwendig ist, sind uns so offenbart, daß sie so viele Winke zu sein scheinen, weiter über diese Wahrheiten nachzudenken" (HKA IX/I, 40). To contemplate the incomplete truths of scripture is also to contemplate its perceived inadequacies. Thus, Klopstock used poetry to elevate the manner in which religious truths were communicated by introducing stronger affects that promise to strengthen a reader's faith in religion.

In poeticizing biblical history Klopstock found himself at the nexus of "fact» and fiction, between what Reinhart Koselleck described as the "osmotish durchlässige [Wände] " that separate the historian from the poet starting around $1750 .{ }^{29}$ Klopstock's epic stood, in other words, on two pillars of authority. On the one hand, by retelling the supposedly true, empirical facts of biblical history in his Der Messias, Klopstock engages in a process of commemoration that extols the exemplars of Christianity. On the other hand, by using the epic form, which was still the preeminent literary genre at the time, ${ }^{30}$ Klopstock energizes those exemplars to persuade his audience to repeat the virtues of the past while avoiding its vices. Yet Klopstock describes his fondness for historical representation in much simpler terms. History, unlike allegory, does not require the labor of abstraction to understand its moral truths. According to Klopstock, "die beiden Hauptfehler der meisten allegorischen Gemälde sind, daß sie oft gar nicht oder doch sehr mühsam verstanden werden, und daß sie, ihrer Natur nach, uninteressant sind " (HKA IX/I, I 48). Klopstock considers allegory »uninteresting « because it forces common sense to view moral truth through a glass darkly. History, by contrast, is more pleasing because it directly appeals to the reader's interest by claiming to represent real people and actual events.

However, Klopstock's epic also aims to transcend history by creating authentic religious experiences through affective poetry. With this in mind, his representation of Thomas should not be understood as an allegory pointing to the dangers of religious skepticism, for John's version already established that. Rather, the reader should affectively experience Thomas's 
historically grounded doubts as the narrative unfolds, and (ideally) become conditioned to suppress any residual skepticism about Christ's miraculous resurrection or the prospect of eternal salvation that is entangled in it. By relating the elocutionary project of "heilige Poesie« to the Thomas episodes of Der Messias a subterranean form of heterodoxy becomes visible. A perspective opens up in which the poem communicates its desire to provide exactly what Thomas requested from Christ: touch. Der Messias seeks to spiritually touch the modern reader-to satisfy their desire to be affectively moved. Yet, in this particular case, it is not Christ's wounds that the audiences touch, but rather Thomas's wounds, which will be explored shortly.

In Der Messias, Klopstock dedicates large sections and nearly an entire chapter to presenting the dramatic effects of Thomas's doubt. By altering the sequence of events, representing the apostle's inner thoughts, and placing Thomas in dialogue with his fellow apostles, Klopstock attempts to harmonize scripture with popular morality. Thus, his poetic amplifications are not without a theological agenda. ${ }^{31}$ Scholars have traced this agenda to neology (I740-I790), ${ }^{32}$ a theological movement committed to forging stronger bonds between reason and faith. Neologians modeled their hermeneutics after Leibniz's Theodicy (I7IO), a text that formulates a central paradox that the group strove to resolve:

But since reason is a gift of God, even as faith is, contention between them would cause God to contend against God; and if the objections of reason against any article of faith are insoluble, then it must be said that this alleged article will be false and not revealed. ${ }^{33}$

Disharmony between faith and reason calls into question the perfection of God, which for Leibniz and his neologian disciples would amount to a contradiction. The »real" problem, therefore, must be linked to discord within human thinking itself - mistakenly grounding beliefs on false articles of faith.

Leibniz was responding to Pierre Bayle's controversial Historical and Critical Dictionary (I 697), which claims that "history is simply a collection of the crimes and misfortunes of the human race. ${ }^{34}$ As far as Bayle was concerned, God should be charged as an accomplice to these crimes of history because he chose not to prevent them even though he had the power to do so. ${ }^{35}$ Leibniz saw things differently. His Theodicy developed a popular counter-narrative that emphasized the "good news" of history. According to Leibniz, the injustices of history can be subsumed under the premise of a greater good, which makes "all the apparent deformities of our little world combine to become beauties [...]. God, by a wonderful art, [...] makes evil serve the greater good. $^{36}$ The antinomy between faith and reason would 
become an enormous site of controversy in the eighteenth-century - one that preoccupied not only the neologians, but also poets like Klopstock, who redeployed the figure of Thomas as a means of subordinating religious skepticism to the "greater good," of the religious community. He does so, for instance, by having Thomas publicly acknowledge his transgression and then ask his peers for forgiveness (something John's version does not do): "Thomas betet' ihm [Christ] nach, stand auf, und ging zu den Jüngern, / Und zu den anderen Brüdern umher, und bat um Erlassung / Seiner Schuld«(HKA IV, I93).

The urgency of Thomas in the context of the eighteenth-century can be detected in Klopstock's decision to present religious skepticism as more widely dispersed throughout the community of believers. In other words, Thomas's incredulity (while extreme) is not exceptional, but appears to be a shared problem that afflicts other apostles. For instance, Peter - the »rock of the church" - attempts to bring Thomas out of the "Betäubung seines Tiefsinns" by identifying with the apostle's doubt: »Auch ich zweifelte, Thomas." On the road to Emmaus, the disciples Kleophas and Matthias also sympathize with Thomas's desire for empirical proof: "wenn wir ihn [Christ] sähen, / O das würd' uns noch mehr, noch mächtiger überzeugen, / Als der stillen Betrachtung Licht, das die Seele mit Wahrheit / Überströmt« (HKA IV, I09)! Decentralizing skepticism so that it is not concentrated solely in the figure of Thomas indicates that modest forms of doubt have a proper place within an economy of faith, while extreme forms need to be contained. Moreover, Peter's characterization of melancholy or »Tiefsinn« as being a consequence of Thomas's skepticism helps to establish why his particular form of skepticism is presented as especially dangerous. Just as Thomas's skepticism is easily communicable so too is his melancholy. For instance, Lebbäus's faith is shaken after his encounter with Thomas. $\mathrm{He}$ confesses that the witness testimony may not amount to a real encounter with Christ; that what they "saw« could have been, at best, signs sent from Christ to assuage their overwhelming grief; at worst, figments of their own overheated imaginations. Upon this recognition, Lebbäus sinks deeper into doubt and Klopstock intentionally brings the two apostles into the same semantic register to underscore a shared melancholy: »Trübe verfinsternde Zweifel / Ließ in den Seelen, die schon verwundet waren, Lebbäus / Traurige Rede zurück" (HKA IV, I 26). "Bleak doubts, " "wounded souls, « and a prevailing sense of "mourning, " qualities that consistently define Thomas throughout Der Messias, are here uttered by a fellow apostle.

More dangerous than the communicability of Thomas's skepticism and melancholy was the fear that it might deteriorate into something worse: atheism. Shaftesbury, who explored the links between melancholy, doubt, and atheism in his A Letter Concerning Enthusiasm (I707), argued that 
"[nothing] besides ill humour can be the cause of atheism. «37 If Klopstock viewed Thomas's radical skepticism as a "prelude to atheism, $«^{38}$ then curing his "sickness" became all the more urgent. Though not just urgent in the sense of bringing some kind of theological "resolution" to the Thomas episode; it was also urgent to the extent that atheism could disturb the rhetorical mechanics of heilige Poesie. Der Messias was designed to renew its readers' enthusiasm for Christianity - to affectively move them into reaffirming its truths. Yet the atheist would resist any such elocution from taking hold if it were thought to issue from a divine source, thereby breaking the chain of enthusiasm that has claimed to link god, poet, and audience since Plato's Ion. ${ }^{39}$ If the audience remains unreceptive to the "unsterbliche Seele» (HKA IV, I) or the muse-like figures that Klopstock invokes at the start of Der Messias, then the project of "Bewegung " would be dead on arrival. ${ }^{40}$ In other words, some degree of belief is a condition of possibility for movement. The prospect that Thomas might convert to atheism constitutes a major site for drama throughout Gesang XIV, which portrays him as a navel-gazing skeptic lacking the enthusiasm of his peers: "Da erhoben alle [the other apostles] die Augen / Still gen Himmel; nur Didymus [Thomas] nicht" (HKA IV, 99). The greatest danger lurking behind Thomas's radical skepticism is that it opens up the door to a thoroughly disenchanted world.

\section{Amplifying Thomas}

Klopstock harshly judges philosophical writing styles that he believes strip the "healthy body" of scripture down to its most naked moral precepts. He writes, "Die Religion ist, in der Offenbarung selbst, ein gesunder männlicher Körper. Unsere Lehrbücher haben ein Gerippe daraus gemacht« (HKA $\mathrm{IX} / \mathrm{I}, 39)$. In other words, translating the moral truths of scripture into philosophical prose diminishes the force of those truths because it abstracts away from the rich particularities of scripture. Klopstock expresses this view most polemically in the essay Von der besten Art über Gott zu denken (I758), in which he concludes that poetry is the best way to think of God because it engages "die ganze Seele« and allows one to abandon "alle Arten von Zweifeln und Unruhen über die unbegreiflichen Wege Gottes« (HKA IX/I, 69). Poetry, he argues, prepares one to »endlich mit der allertiefsten Unterwerfung [...] Gott lieben können« (HKA IX/I, 69). Klopstock's critique of a »kalte metaphysische Schreibart" pejoratively calls into question the efficacy of moral precepts to guide an imagined public towards virtuous life. At one point, Klopstock mocks this cold metaphysical style by making "die Sprache into a person submitting to its rules. In the following passage, she laments being confined by the narrow conventions of scholasticism: 
Mich (denn heute darf ich von mir selbst reden) sollen Schulmethode, Armseligkeit am guten Ausdrucke, und jene überflüssigen Untersuchungen verstellen, die nichts weniger, als die Kenntnis der Menschen und ihre Verbessrung angehn. Ich sei nicht mehr die Führerin und die Freundin des gesunden Verstandes, sondern eine Grüblerin, welche die von ihr erhitzte Einbildungskraft vergebens zu fesseln sucht. (HKA IX/I, 93)

The "Schulmethode" used by the philosopher, making language into a "Grüblerin« as Klopstock describes it here, curbs the creative potential of a more poetically stylized language, which Klopstock regards as essential for communicating sublime religious truths. It is of interest to this inquiry that Klopstock also uses the term "grübeln" to describe Thomas in Der Messias, linking the apostle explicitly to a mode of thinking defined by both excessive brooding and a lack of creativity (HKA, XIV, 99).

However, even if a more poetically stylized mode of communication enjoys greater freedom and has more "success « than philosophy, what could the poet possibly add to scripture if it already represents a "gesunder männlicher Körper" (HKA IX/I, 39)? Klopstock eludes this question through gestures of piety, and yet he insists that some parts of scripture require poetic amplification. Some stories, Klopstock writes, are designed "mit so wenigen Worten, daß wir notwendig Umstände hinzudenken müssen, um sie uns vorzustellen" (HKA IX/I, 40). Thus, from the standpoint of Klopstock's poetics, certain scenes of the bible are more "healthy" than others, and poetry (not philosophy) should be called on to elaborate them.

As noted above, Klopstock avoids using densely coded allegories to fill in these missing circumstances of scripture because they would require specialized hermeneutic training to decode. History, by contrast, supplies exempla that are »für die meisten die einzige Reizung, die ihnen übrig ist, mindestens einige Stufen der Tugend zu ersteigen. Denn die Aussprüche der Pflicht sind ihnen zu kalt. Sie wirken nicht auf ihr Herz" (HKA IX/I, 83). The advantage of historical narration is, in part, that it opens up an affective route to grasping religious truth; a route that doesn't require extensive knowledge of the "Schulmethode. "This perspective that Klopstock maintains across his aesthetic writings constitutes a challenge to the Aristotelian tradition. ${ }^{4 \mathrm{I}}$ Whereas Aristotle distinguishes between the particular truths of the historian from the general truths of the poet and philosopher, Klopstock finds that the particular truths of biblical history (i. e., exempla of virtue) already function as general truths insofar as they communicate actions and deeds worthy of social reproduction. Poetry serves to amplify, intensify, or even repurpose these particular truths of history in novel ways. ${ }^{42}$ Therefore, Klopstock's religious poetry is not limited to telling of what might happen, but instead claims to tell of what is and of what has been; his task is to 
carefully follow in the "Fußtapfen der Offenbarung (HKA IX/I, 40) and express in more rich detail what the Evangelists already left behind:

Der Theil der Offenbarung, der uns Begebenheiten meldet, besteht meistenteils nur aus Grundrissen, da doch diese Begebenheiten, wie sie wirklich geschahn, ein grosses, ausgebildetes Gemälde waren. Ein Dichter studiert diesen reichen Grundriß, und malt ihn nach den Hauptzügen aus, die er in demselben gefunden zu haben glaubt (HKA IX/I, 33).

Klopstock's analogy between poetry and painting suggests that he does not invent any new subject matter, but instead, like an apprentice painter, merely adds a splash of color to the fading figures left behind by the master painters (i. e., the Evangelists). However, adding more color to the outlines of any ancient painting runs the risk of both defacing the original and of narrating the "great painting" of biblical history more vividly than its sources. ${ }^{43}$ So the following question remains unanswered: what exactly does Klopstock add to scripture?

I argue that Klopstock adds "Darstellung" to scripture. Klopstock's concept of "Darstellung" has been the subject of much scholarship, ${ }^{44}$ and it is primarily concerned with activating the audience's sensibilities through novel expressions of language. To this end, Klopstock manipulates rhythm, meter, and tone to create "Wortbewegung" and a sense of "Lebendigkeit" that the audience experiences during public readings of his poetry. The expressed goal of "Darstellung « involves alienating the audience from familiar expressions in order to lead them into new horizons of thought and feeling. ${ }^{45}$ Accordingly, "Darstellung « breaks with earlier aesthetic paradigms that produce what Klopstock disparagingly refers to as "bloße Vorstellungen" (HKA IX/I, 352). By advancing a dynamic aesthetic regime, Klopstock is more preoccupied with transmitting the affective force of an object or state of mind than he is with presenting an object as such. However, this implies that the object of Der Messias, sacred history, becomes a means to an end; an end seeking to produce powerful affects designed to help readers (re)affirm the particular truths and exempla of scripture. But, as Bernd Aueroch points out in his book Die Entstehung der Kunstreligion, this produces a coercive situation whereby "heilige Poesie« asks its readers to appreciate religious poetry not for its aesthetic and literary qualities, but instead for its status as »sacred. $«^{46}$

Ethical difficulties emerge once "Darstellung « is linked to the audience's desire to be moved. Klopstock claims, »dass ihn [den Zuhörer] etwas bewege, dies ist das heißeste Dürsten unseres Geistes; er liebt alles, was so ihn erquickt" (HKA II, 54). The primacy of »Bewegung" does not square well with the discourse of exemplarity, given that there can be no guarantee one 
will be moved in the direction of virtue. If anything and everything can move the audience, then moral edification is contingent given its subordinate position in Klopstock's poetics. ${ }^{47}$ Nevertheless, Klopstock remains confident that "höhere Poesie« is incapable of leading its audience to vice:

Die höhere Poesie ist ganz unfähig, uns durch blendende Vorstellungen zum Bösen zu verführen. Sobald sie das tun wollte, hört sie auf zu sein, was sie ist. Denn so sehr auch einige sich selbst klein machen wollen, so können sie sich doch niemals so weit herunterbringen, dass sie etwas anderm, als was wirklich edel und erhaben ist, diese große und allgemeine Bewegung aller Kräfte ihrer Seele erlaubten. (HKA IX/I, 36)

Klopstock clearly assumes a pre-established harmony between virtue and sublime representations. In order for sublime representations to "move the entire soul « of an audience, there must be something recognizably virtuous in them. Recognizing virtue is thought to trigger a response or "movement" in the listener that harmonizes their faculties (i.e., the imagination, the understanding, and the will). But if virtue were a condition of art, then the artist would no longer be governed by the spontaneity of genius, but instead by an ethos or doctrine. ${ }^{8}$ These tensions within Klopstock's own poetics serve as a background for reflecting on the figure of Doubting Thomas, whose virtue has been understood as limited. ${ }^{49}$ If "höhere Poesie" strives to coordinate sublime art and biblical history to move the audience towards virtuous life, then why dedicate nearly an entire chapter to a figure who holds the status of a negative example?

In Der Messias, Thomas's sole conviction is that he will not believe. "Wenn ich, «Thomas proclaims, »mit bebendem Arm um deine Füße mich winde, / Und sie halte: dann will ich glauben! Ich werde nicht glauben" (HKA IV, I 20)! Klopstock often juxtaposes the subjunctive with the indicative to emphasize how Thomas's desire to believe never triumphs over his demand for direct evidence. Doubting Thomas, as a negative exemplar, shows how faith and reason will remain out of tune unless he allows indirect routes to harmonize his convictions. By indirect routes, I mean he must allow the stories of witnesses to make impressions upon his sensibilities (Empfindsamkeit) - not just his understanding (Verstand). Unlike Leibniz, who tasked reason alone with the labor of distinguishing between true and false articles of faith, Klopstock allows feeling to participate in this work. ${ }^{50}$ In Thomas's most spiritually desperate moment - the point at which he realizes he still cannot believe even after his guardian angel appeared to him - he asks himself: „Wer schmachtet so nach Überzeugung, als ich?" (HKA IV, 99) On the one hand, this could mean that nobody yearns for conviction more than Thomas (comparative); that is, no one stands more in need 
of external assistance than he. Yet, it could also mean that nobody yearns for conviction quite like Thomas does (modality). The latter reading suggests that Thomas's skepticism displays a mode of thinking that closes off all other means for establishing conviction-reason alone provides the path.

\section{Treating Thomas's Skepticism}

An early exchange between Thomas and his peers generates a textual ambiguity that invites readers to identify "Schwärmerei« among the community of believers. It is only later, after Thomas's skepticism gives way to a deadly form of melancholy, that he emerges as the unlikely "Schwärmer« of the group. Thomas's initial reaction to witness testimony offers a good starting point to consider both this ambiguity and the nature of his skepticism:

Itzt seyd ihr [die Jünger] zu lebhaft / Durch das alles getäuscht, was ihr [Maria Magdalene und andere weibliche Zeugen] erzählet. Ich werde, / Wenn ihr es erst zu tragen vermögt, der Zweifel Ursach, / Welche mir anders zu denken gebeut, euch offen entdecken, / Nichts verschweigen! Ihr glaubt, ihr Jünger Jesus, die Mährlein, / Die sie erzählen, doch nicht? (HKA IV, 99)

After observing how enthusiastically (»lebhaft") his peers accept the news of Christ's miraculous resurrection, Thomas immediately grows suspicious and searches for all the possible sources of his doubts. One of those sources arises from misogyny insofar as Thomas mistrusts female witnesses and targets their gender as a way to discredit the reports, even referring to them as a little fairytale (»Mährlein«). That his male counterparts would cheerfully believe in this "fairytale» leads Thomas to believe that they were "getäuscht." Consequently, Thomas thinks his religious community is seeing things that have no basis in reality, which introduces the discourse of "Schwärmerei« into the poem. Thomas's doubts will only be dispelled if he discovers a natural explanation for what appears to be a supernatural event a demand echoing eighteenth-century deism. ${ }^{51}$ At the same time, Thomas's mandate that nothing be concealed ("nichts verschweigen! «) demonstrates an intolerance for all forms of mystery or uncertainty, which generates the melancholy from which Thomas cannot escape through his own powers.

The apostles of Der Messias all work hard to dispel Thomas's doubts so that he too can participate in their faith. But despite their best efforts, Thomas's stubborn proclivity for excessive brooding always seems to prevail. This was the case even before any witness testimony of Christ's resurrection. For instance, readers are first introduced to Thomas by Umbiel, his guardian angel, who portrays him as lost in a labyrinth of his own making: 
Umbiel sprach ferner: Der dort voll Gedanken und einsam / Tief in dem Walde sich zeigt, ist Thomas, ein feuriger Jüngling. / Stets entwickelt sein Geist aus Gedanken Gedanken! Ihr Ende / Findet er oft nicht, wenn sie sich vor ihm, wie Meere, verbreiten! / Bald hätt' er sich in dem finstern Gebäu des träumenden Saddok / Kläglich verloren; allein des Messias gewaltige Wunder / Retteten ihn, er verließ die labyrinthischen Irren, Kam zu Jesus. (HKA IV, 5I-52)

Umbiel's description establishes a link between Thomas's excessive brooding and melancholy. As the passage indicates, Thomas's entire spiritual life is organized around boundless reflection, which he experiences like a vast ocean - an image alluding to the concept of the sublime. This image, combined with the fact that his reflections "often find no end " and transport him deep into the forest away from any social or ethical life, produces a "negative presentation" of the sublime that Kant and others identify as "Schwärmerei. «\$2 Moreover, by referring to Thomas's previous system of belief (»Zaddok") as a »dark building " the text introduces the idea of moral inferiority that Freud later associates with the melancholiac's desire to abandon life - a desire that Thomas expressly shares after Christ's death. ${ }^{53}$

Thomas's prior affiliation with the "Saddok« requires further examination since Peter also references it during a heated exchange between the two disciples. The Sadducees were an elite Jewish sect that rejected the idea of revealed knowledge involving supernatural spirits, eternal salvation, and the resurrection of Christ. ${ }^{54}$ After repeated attempts to assuage Thomas's "qualenvolle Gedanken, " Peter grows fatigued and accuses Thomas of allowing his skepticism to blind him from seeing the truth:

Deine [Heftigkeit] blendet sich nur, mit der du zweifelst! Wir sahen! / Und wir wurden entzückt! [...] Du siehst nichts! schaffest dir Schatten, / Bange Bilder von Gräbern und Nacht, erschreckende Zweifel! [...] Geh zu den Sadducäern zurück, und glaube mit ihnen, / Daß kein Engel, noch Geist sey, noch Auferstehung vom Tode! (HKA IV, IIs)

Thomas's blindness is, according to Peter, willful considering that the group reached a consensus regarding the veracity of witness testimony. Peter's ultimatum is clear: if Thomas cannot accept the truth of Christ's resurrection, then he faces exile from the community of believers. Curiously, exile is precisely what Thomas prefers. He remains adamant about having a personal experience with Christ, and, in a display of jealous confusion, asks: "Euch nur erschiene der Herr? nicht mir?" (HKA IV, I I6) Thomas, quite reasonably, rejects the idea that Christ would appear only to the others, and decides to search for peace in a nearby graveyard. 
The graveyard scene involves a combination of prayer and soliloquy in which Thomas performs the kind of self-examination Shaftesbury prescribes in his A Letter Concerning Enthusiasm. ${ }^{55}$ The aim of self-examination is to clear matters up; to observe if one is in a condition to impartially judge the testimony of others. However, in the graveyard Thomas becomes so overwhelmed by melancholy that he contemplates suicide: "Möcht' ich liegen bey ihm [dem toten Körper Christi] und schlummern, müde von Wunden / Meiner Seele!« (HKA IV, I I 7) Thomas's melancholic condition makes him an unsuitable judge and brings the procedure of self-examination to an abrupt end. Religious contemplation, Shaftesbury argues, often leads to melancholy and makes self-examination impossible:

The melancholy way in which we have been taught religion makes us unapt to think of it in good humour [...]. We can never be fit to contemplate anything above us when we are in no condition to look into ourselves and calmly examine the temper of our own mind and passions. ${ }^{56}$

Finding no peace on his sojourn through the graveyard, Thomas becomes more intensely afflicted by his brooding. The apostle's guardian angel enters at the moment when his skepticism becomes most (self-)destructive: "Wessen ist diese Klage, die aus den Gräbern hervorschallt? / Fiel dich ein Mörder an? Und kann ich dir helfen, o Fremdling? / Rede! Wo bist du? Ich will dir deine Wunde verbinden" (HKA IV, I 20). Thankful but reluctant to accept the angel's offer, Thomas is again convinced that his "wounded soul« could only be healed through the direct evidence of Christ's appearance. Before taking leave of Thomas, the angel recommends that he "Schau gen Himmel, und lerne mit Furcht und Zittern klagen! / Freuen sollen wir uns mit Furcht und Zittern, so sollen / Wir auch klagen" (HKA IV, I 2 I). The allusion to Philippians 2:I 2 is apt, given that Paul composed these lines while in prison and uncertain of his own fate. Here Paul recommends that one "be of the same mind as Christ" and act not out of self-interest but from fear and trembling, which is to act as if Christ were present despite his actual absence. The implied presence of Christ should suffice to regulate Thomas's thoughts and actions in a pragmatic sense. ${ }^{57}$ But Thomas is in no condition "to look up, " he finds himself imprisoned by melancholy, completely impartial, and driven by a seemingly selfish desire for more empirical evidence. Klopstock's amplification of Thomas becomes most polemical in the graveyard. He strongly advises against following Thomas's skeptical path of despair by implying that it could end in suicide.

A final observation to take away from the graveyard scene is perspectival. Thomas's guardian angel introduced him as isolated and brooding in the Garden of Gethsemane, the place where Jesus succumbed to doubt in the 
Gospels of Matthew and Mark. ${ }^{58}$ The later graveyard scene also occurs in the "fernsten Gräbern des Ölbergs, " the location of Christ's doubt in the Gospel of Luke. ${ }^{59}$ Klopstock, therefore, attempts to bring Thomas and Christ into relation as doubting figures. Yet to accomplish this Klopstock must abandon the Gospel of John - the only gospel in which Thomas and Jesus directly communicate - and turn to the synoptic Gospels for his amplification of Jesus's doubt. In John's narrative, Jesus courageously accepts his fate, whereas the other Gospels acknowledge a profound moment of hesitation. ${ }^{60}$ Klopstock's decision to do this is a deliberate synthesis of scripture that attempts to elevate one mode of doubt over another.

It is especially interesting to reflect on Klopstock's innovative use of scripture in the light of apocryphal literature, which portrays Thomas as Christ's twin brother. ${ }^{6 \text { I }}$ The name "Didymus, " which Klopstock repeatedly uses to refer to Thomas, means "twin." It is as if Klopstock built this possibility into his narrative strategy, expecting his readers to identify Thomas as the weaker brother who cannot rise above his own limited perspective. Thus, the two modes of doubt serve as contraries; Thomas finds himself in exile, staring into a grave, while Christ emerges triumphantly from his moment of doubt. Gesang V of Der Messias depicts Christ at his most skeptical moment:

Hast du [Gott] mit ausgebreitetem Arm den Kelch der Leiden / Über mich ausgegossen? Ich bin ganz einsam, von allen, / Die ich liebe, den Engeln; den Mehrgeliebten, den Menschen, / Meinen Brüdern [...] Doch nicht mein Wille geschehe! / Vater, dein Wille geschehe! Mein hingeheftetes Auge / Schauet aus in die Nacht, und kann nicht weinen; mein Arm bebt, / Starrt nach Hülfe gen Himmel empor; ich sink' auf die Erde: / Sie ist Grab! Es ruft, durch alle Tiefen der Seele, / Laut ein Gedanke dem andern: Ich sey von dem Vater verworfen! (HKA IV, III)

Descriptions of complete isolation, peering out into darkness, and sinking into the earth show striking parallels with Thomas's doubts in Gesang XIV. However, the difference between the contrary modes of skepticism is that Christ's doubts are always regulated by the presence of another person's will, imagined or real. The mode in which Christ doubts reflects the theological concept of kenosis, which refers to precisely this moment when he empties out his individual will in order to make room for a divine will. Similar to Job's inwardly determined faith, this aids Christ in rising above the fears and anxieties occasioned by his doubts. The result is a reintegration of the self into social and ethical life-a belief that his imminent death will have future significance. Thomas's insistence on further evidence, by contrast, chains him to a dangerous form of melancholy that paves the way 
to suicide. Their contrary modes of doubting produce two fundamentally different ways of seeing the world, which Klopstock characterizes at the conclusion of »Von der heiligen Poesie«: »Der Freygeist, und der Christ, der seine Religion nur halb versteht, sehn da nur einen grossen Schauplatz von Trümmern, wo der tiefsinnige Christ einen maiestätischen Tempel sieht« (HKA IX/I, 43). Thomas's spirit is "free" in the sense that it is trapped in a state of indeterminacy. He fails to see the majestic temple that Christ and his peers see because he fails to make proper use of his imagination.

Yet despite Klopstock's attempt to revitalize the moral lesson that it "better to believe than to see, « there remains much to celebrate in his representation of Thomas. He refuses to yield to the will and testimony of others through faith alone; he exemplifies the spirit of autonomy; he thinks and acts according to self-imposed principles, and he maintains a rigorous method of investigation. By linking Thomas to Christ through their shared experiences of doubt, the reader is in a position to compare Christ's arguably naive optimism with Thomas's seemingly futile search for truth. Klopstock's Thomas remains a split exemplum - one that forces the reader to choose between two uncertain modes of doubt, lucidly captured by the etymology of the word "zweifeln." As I have suggested throughout, Klopstock can only hope that his audience will be moved to imitate the more virtuous mode of skepticism - whichever one that may be.

\section{Bilkent University, Turkey}

I Friedrich Gottlieb Klopstock, Werke und Briefe. Historisch-Kritische Ausgabe (HKA), vol. I, ed. by Horst Gronemeyer, Elisabeth Höpker-Herberg, Berlin 20IO, Pp. I44-I 58 ; I60-I69.

2 Johannes 20:28. To compose Der Messias Klopstock relied heavily on Luther's translation of the Bible, finding Luther's innovative use of the German language to be a source of inspiration. Martin A. Hainz, Silbenzwang. Test und Transgreß bei Friedrich G. Klopstock, unter besonderer Berücksichtigung des Messias, Tübingen 2017, pp. 29-32.

3 Job i 9:25-27.

4 Mark I6:6-8.

5 Luke 24:37; 24:38-39; 24:4I-43.

6 Matthew 28:17.

7 Glenn Most, Doubting Thomas, Cambridge, Mass. 2005, pp. 27-28.

8 John 20:29.

9 John 20:28; 20:1 5.

IO John 20:25.

I I Kevin Hilliard's research discusses the figure of Thomas in Klopstock's Messias, though he subsumes Thomas's relevance under the discourse of "freethinking" and does not venture a comparison between the underlying poetics of Der Messias 
and the figure of Thomas as I do here. See Hilliard, Freethinkers, Libertines and Schwärmer. Heterodoxy in German Literature, I750-1800, London 200I, pp. 63-68. Steffen Martus analyzes Klopstock's version of Doubting Thomas, but limits his investigation to showing how the Thomas scenes establish an environment of "critical communication, " which asks the reader to become a disciple of Klopstock's rather than the Messiah's. Steffen Martus, Werkpolitik. Zur Literaturgeschichte kritischer Kommunikation vom I7. bis ins 20. Jahrhundert, Berlin 2007, pp. 279-8I.

I 2 Immanuel Kant, Beantwortung der Frage: Was ist Aufklärung?, in: Werke in Zwölf Bänden, vol. I I, ed. by Wilhelm Weischedel, Berlin 20I4, pp. 53-6I.

I 3 Immanuel Kant, Kritik der reinen Vernunft I, vol. 3. p. 30.

I4 Immanuel Kant, Kritik der reinen Vernunft I, vol. 3. p. 2 I9.

I 5 See Spinoza, Theological-Political Treatise, trans. by Michael Silverthorne and Jonathan Israel, New York 2007, p. 98.

I6 Gotthold Ephraim Lessing, Werke und Briefe in zwölf Bänden, vol. 8, ed. by Wilfried Barner a.o., Frankfurt a. M. 1989, p. 346.

I7 Lessing, Werke und Briefe, vol. 8, p. 440.

I 8 The allusion is to Blake's famous epithet on Milton. William Blake, Collected Works, New York I988, p. 35.

I9 Gerhard Kaiser, Klopstock. Religion und Dichtung, Gütersloh 1963, p. 9. For further scholarship on this topic see: Joachim Jacob, Heilige Poesie. Zu einem literarischen Modell bei Pyra, Klopstock und Wieland, Tübingen I997, pp. I35I 57 .

20 Kevin Hilliard, Der Skeptizismus in der deutschen Aufklärung und die literarischen Folgen, in: German Life and Letters, vol. 62 (2009), pp. 7-20; here p. 7.

2 I Most (endnote 7), p. I45.

22 John 20:29.

23 Most, pp. I 44-I 45.

24 Jerusalem offered Klopstock a teaching post at the Collegium Carolinum to help financially support the completion of Der Messias, but Klopstock refused.

25 Augustine, On Free Choice of the Will, trans. by Thomas Williams, Indianapolis 1993.

26 Johann Friedrich Wilhelm Jerusalem, Schriften, vol. 4, ed. by Andreas Urs Sommer, Hildesheim 2007, p. 433.

27 Kaiser (endnote 19), Klopstock. Religion und Dichtung, pp. 9-27.

28 Katrin Kohl, Die sbeste Art über Gott zu denken?? Auseinandersetzungen um das religiöse Potential der Dichtung im I 8. Jahrhundert, in: Literatur und Theologie im I 8. Jahrhundert. Konfrontationen, Kontroversen und Konkurrenzen, ed. by Hans-Edwin Friedrich, Wilhelm Haefs, Christian Soboth, Berlin 20 I I, pp. 225243; Hilliard, Philosophy, Letters, and the Fine Arts, London 1987, pp. 68-69.

29 Reinhart Koselleck, Vergangene Zukunft. Zur Semantik geschichtlicher Zeiten, Frankfurt a. M., 2013, p. 279.

30 Johann Jacob Breitinger, Critische Dichtkunst, vol. I, ed. by Paul Böckmann and Friedrich Sengle, Stuttgart 1966, pp. 77-106; Charlton Payne, The Epic Imaginary: Political Power and its Legitimations in Eighteenth-Century German Literature, Berlin 20I 2, pp. 6I-74.

3 I Breitinger, Critische Dichtkunst, p. I97. 
32 Kaiser (endnote I9), pp. 28-35.

33 Gottfried Leibniz, Theodicy, ed. Austin Farrer, trans. by E. M. Huggard, La Salle, IL I 990, pp. 96-97.

34 Pierre Bayle, Historical and Critical Dictionary, Selections, trans. by Richard H. Popkin, Indianapolis I991, p. I47.

35 Susan Nieman, Evil in Modern Thought: An Alternative History of Philosophy, Princeton 2002; Odo Marquard, Apologie des Zufälligen, Stuttgart 1986.

36 Gottfried Leibniz, Theodicy, p. 216; Leibniz, On the Ultimate Origination of Things (1697), in: Philosophical Essays, trans. by Roger Ariew and Daniel Garber, Indianapolis 1989, p. I 53.

37 Shaftesbury, Characteristics of Men, Manners, Opinions, Times, ed. by Lawrence E. Klein, Cambridge I999, p. I3.

38 Hilliard, Freethinkers, Libertines and Schwärmer, p. 62.

39 Plato, Ion, in: Collected Dialogues, ed. by Edith Hamilton and Huntington Cairns, Princeton 2005, pp. 221-222.

40 Peter Fenves, The Scale of Enthusiasm, in: Klein and La Vopa, Enthusiasm and Enlightenment, pp. II7-I 53; Shaftesbury (endnote 37), Characteristics, pp. 2728, 365-379.

4I Aristotle, The Complete Works of Aristotle. Revised Oxford Translation, vol. I \& 2, ed. by Jonathan Barnes, Princeton i984, p. 4979.

42 Matthew Roller, Exemplarity in Roman Culture: The Cases of Horatius Cocles and Cloelia, in: Classical Philology, vol. 99, no. I (2004), pp. I-56.

43 Hans Belting, Likeness and Presence: A History of the Image before the Era of Art, Chicago I994, p. 267.

44 Hainz (endnote 2), pp. I73-I79; Winfred Menninghaus, Klopstocks Poetik der schnellen Bewegung, in: Gedanken über die Natur der Poesie. Dichtungstheoretische Schriften, Frankfurt a.M. I989, pp. 259-36I; Winfred Menninghaus, Darstellung: Friedrich Gottlieb Klopstocks Eröffnung eines neuen Paradigm, in: Was heißt "Darstellen«? ed. by Christian L. Hart Nibbrig, Frankfurt a. M. I 994, pp. 205-226; Kerstin Behnke, Toward an Understanding of Romantic Darstellung, in: The Spirit of Poesy: Essays on Jewish and German Thought, ed. by Richard Block and Peter Fenves, Evanston, IL 2000, pp. 60-74.

45 Klopstock uses the word "Täuschung" to describe the goal of "Darstellung" in his essay "Von der Darstellung." I view alienation as an effect of this (HKA IX/I, 363).

46 Bernd Auerochs, Die Entstehung der Kunstreligion, Göttingen 2006, p. 204.

47 Menninghaus, Klopstocks Poetik (endnote 44), pp. 306-3 I 8.

48 Klopstock asserts, „Die höhere Poesie ist ein Werk des Genies« (HKA IX/I, 35).

49 Rudolf Bultmann, The Gospel of John. A Commentary, trans. by G. R. BeasleyMurray, ed. by R. W. N. Hoare and J. K. Riches, Philadelphia I97 I, p. 694.

50 See note 33 above.

5I For a relevant example of deism see Reimarus, Drittes Fragment. Durchgang der Israeliten durchs rote Meer, in: Lessing, Werke und Briefe, vol. 8, p. 236-237.

52 Kant, Kritik der Urteilskraft, Leipzig 1986, p. 20I; Jean-François Lyotard, Lessons on the Analytic of the Sublime, trans. by Elizabeth Rottenberg, Stanford I 994 , pp. I $50-153$.

53 Sigmund Freud, The Freud Reader, New York I 995, p. 584. 
54 On the Sadducees see Mark I2:I 8-27, Matthew 22:23-33, and Luke 20:27-40; also Josephus, "The Antiquities of the Jews" and »The War of the Jews, « in: The Complete Works, trans. by William Whiston, Thomas Nelson, Nashville I 998.

55 Shaftesbury (endnote 37), Characteristics, p. 28.

56 Shaftesbury, Characteristics, pp. I7-18.

57 Kant (endnote 52), pp. 294-298.

58 Matthew 26:36-46; Mark I 4:32-52.

59 Luke 22:39-46.

60 Compare John i 8:I I and Matthew 26:39.

6I The Apocryphal New Testament: A Collection of Apocryphal Christian Literature, ed. by J. K. Elliot, Oxford I993, p. 460. 